\title{
No adverse inference for failure to obtain or disclose opinion
}

The Court of Appeals for the Federal Circuit has issued its longawaited ruling concerning the state of US patent law with respect to determinations of wilful infringement. In an en banc decision in which all the justices consider the issues, the court abolished the adverse inference rule that penalized defendants for declining to reveal the contents of a legal opinion analysing their patent rights during a trial. The adverse inference rule was established to ensure that potential infringers obtained non-infringement legal opinions before going forward with any possible infringing activities. Until now, a company is presumed to have wilfully infringed a patent if it declines to produce an opinion of non-infringement from its attorneys. A finding of wilful infringement makes a defendant liable for up to treble damages, as well as payment of the plaintiff's attorney fees.

The case in question involves a German company, KnorrBremse, which sued Dana and Haldex corporations for violating its patent (US 5,927,445) on air-disc brakes. A district court found infringement but awarded no damages because no infringing devices were sold. However, the court awarded Knorr-Bremse about US $\$ 700,000$ for attorney fees and court costs, ruling that the patent had been wilfully infringed because one of the defendants failed to obtain an opinion letter and the other refused to produce its letter at trial. The Federal Circuit has sent the case back to the district court for re-determination with instructions to consider the totality of the circumstances, but without the presumptive weight of an adverse inference that was or would have been unfavourable.

The Federal Circuit followed an unusual course in deciding voluntarily to hear the case en banc. A call for amicus briefs (documents filed by third parties) resulted in a number of opinions from intellectual property groups, the Securities Industry Association and national organizations, including the American Bar Association, all in support of abandoning the doctrine. The court overturned the rule in a 10-to-1 opinion by Judge Pauline Newman.

Knorr-Bremse Systeme Fuer Nutzfahrzeuge GMBH versus Dana Corp. et al: http://www.fedcir.gov/opinions/01-1357.doc

\section{Federal Circuit law trumps regional circuit law}

In an appeal challenging a district court's decision to prevent another district court's consideration of a parallel litigation filed just four hours later, the Court of Appeals for the Federal Circuit determined that its own law, rather than regional circuit law, should govern whether the district court's injunction can be appealed against.

Chiron owns several US patents for methods relating to the detection of hepatitis $C$ virus in blood. LabCorp supplies products for testing for hepatitis C virus. In late 2002, Chiron informed LabCorp that it would file a patent infringement complaint against them unless LabCorp signed a standstill agreement and began licensing negotiations. After LabCorp failed to sign a proposed extension to a second standstill agreement in April 2003, Chiron filed suit for infringement in the District of Northern California, seeking damages and an injunction against LabCorp's manufacture, use and sale of a number of products. However, only hours earlier LabCorp had filed a complaint against Chiron in Delaware, seeking a judgement that LabCorp were not infringing Chiron's patents and that the Chiron patents are invalid. During the course of litigation, the Delaware District Court granted LabCorp's motion to force Chiron to drop the second-filed action that was then co-pending in California.

On appeal, the Federal Circuit first considered whether to follow Federal Circuit law, in which such injunctions can be appealed against, or regional law, in which they cannot. Referring to the policy underlying its own jurisdiction - the maintenance of national uniformity in patent cases - the Federal Circuit interpreted prior case law to permit the application of Federal Circuit law. The court upheld the decision to force Chiron to withdraw the California suit.

Laboratory Corp. of America Holdings et al. versus Chiron Corp.: http://www.fedcir.gov/opinions/03-1572.doc

\section{Infringement reversed in AstraZeneca versus Mutual}

The Federal Circuit has ruled that Mutual Pharmaceutical Co. did not infringe AstraZeneca's patent US 4,803,081 relating to extended-release formulations of felodipine. Mutual recently filed an Abbreviated New Drug Application for its own extended-release felodipine tablets.

Many extended-release formulations use 'solubilizers', a term that both parties agree covers the use of three types of chemicals: surface-active agents; co-solvents; and complexations. AstraZeneca claims that its patent covers all three classes of solubilizer used in the formulation of felodipine, and therefore Mutual's drug — which uses a co-solvent - infringes the '081 patent. However, the Federal Court held that the '081 patent clearly describes the solubilizers as surface-active agents in several parts of the claim, and therefore sheds light on the proposed use of the claim.

This highlights the complexity of claim construction law: in this case, the intrinsic evidence (the description of a particular 'solubilizer') overrules the ordinary meaning of a particular term (other classes of solubilizer). The Federal Circuit disagreed with AstraZeneca's contention that this case should be remanded to address the doctrine of equivalents - that is, where the accused device or method is thought to be equivalent to the patented material and therefore infringes that patent, even if no literal infringement of the claim exists.

AstraZeneca versus Mutual Pharmaceutical Co.: http://www.fcplc.org

\section{PATENT ADVISORS}

Leslie Meyer-Leon: IP Legal Strategies Group, Cape Cod, MA, USA Philip Webber: Frank B. Dehn \& Co. London, UK 